\title{
Import of Electronic Waste into Nigeria: the Imperative of a Regulatory Policy Shift
}

\author{
Emeka P AMECHI \\ Senior Lecturer, Faculty of Law, University of Port Harcourt, Choba, \\ Rivers State, Nigeria \\ e.amechi@gmail.com
}

\author{
Babatunde A ONI \\ Associate Professor, Faculty of Law, University of Lagos, Akoka, \\ Lagos State, Nigeria \\ tundeoni20o6@gmail.com
}

\begin{abstract}
This article explores the regulation of transboundary movement of e-waste into Nigeria. The country has had an unsavoury history with the transboundary movement of hazardous wastes, and this has likely influenced its strict legislative response to such imports, including the decision to ban the transboundary movement of e-waste. However, the effectiveness of the ban is doubtful, as the importation of non-functional electrical and electronic equipment (EEE) or near-end-of-life EEE (which is classified as e-waste in Nigeria), is still thriving. The failure of the ban in curbing the transboundary movement of e-waste into Nigeria obliges policy makers to come up with new and innovative means to address this issue. It posits that the ban does not show an appreciation of the socio-economic realities and the generally weak regulatory climate in the country. The article thus argues for a shift in policy from outright ban of e-waste imports into Nigeria to more effective regulation and sustainable management.
\end{abstract}

\section{Keywords}

e-waste - transboundary movement - electrical and electronic equipment regulation - Nigeria - Ghana 
There is no doubt that many African countries are feeling the negative impacts of the transboundary movement of electrical and electronic waste, popularly known as e-waste, as the region is emerging as a destination of choice for the dumping of such waste. ${ }^{1}$ The trend is fuelled by the high level of consumption of electrical and electronic equipment (EEE), particularly used and discarded equipment imported from mostly developed countries. ${ }^{2}$ Such imports have clearly been vital in bridging the difference in digital access between African countries and developed countries (the digital divide), and consequently, improving the socio-economic development of their citizenry. ${ }^{3}$ However, the increased consumption of used EEE in Africa has led to a corresponding increase in volumes of e-waste generated within the region. E-waste is variously defined in different contexts to involve waste electrical electronic equipment (WEEE) including old, discarded or end-of-life EEE. ${ }^{4}$ It is reputedly the fastest-growing waste stream in the world. ${ }^{5}$ The waste poses significant human health and environmental challenges when improperly disposed of, due to the presence of several lethal chemicals or substances contained in such wastes, including heavy metals such as mercury, lead, beryllium, bromine and organic compounds of chlorine. ${ }^{6}$ Such risks are magnified in Africa due to the crude

1 J SIMPSON, Africa Emerging as E-Waste Dumping Ground (Toxics Alert, December 2006). <http://http://enews.toxicslink.org/news-view.php?id=3>.

2 Ibid.

3 Access to information communication technology (ICT) has been recognized as one of the indicators of a country's socio-economic development. See Secretariat of Basel Convention (sвC), Where are WEee in Africa? Findings from the Basel Convention E-waste Africa Programme (December 2011) 15 <www.basel.int/Portals/4/download.aspx?d=UNEP -CHW-EWASTE-PUB-WeeAfricaReport.English.pdf> (hereinafter 'sBC';) and Ministry of Information and Communication Technology (ICT), Electronic Waste (E-Waste) Management Policy for Uganda (2012), 10 <www.ict.go.ug/sites/default/files/Resource/Electronic\%20 Waste\%20 Management\% 20Policy\%2ofor\% 2oUganda.pdf $>$.

$4 \operatorname{sвC~}\left(n_{3}\right) 7$, defines E-Waste as 'Electrical and electronic equipment that is no longer suitable for use or that the last owner has discarded'; see also the Abuja Platform on E-Waste, a communiqué issued by the International Conference on E- Waste Control, Abuja,20-21 July 2009.

5 Toxics Link, E-Waste in India: System failure imminent — take action NOW! (2004) $1<$ http:// toxicslink.org/docs/o6o40_repsumry.pdf. See also A BIDWELL, 'U.N. Seeks to Solve Growing Global E-Waste Problem' U.S. News and World Report (16 December 2013)<www.usnews.com /news/articles/2013/12/16/un-seeks-to-solve-growing global-e-waste-problem> Department of Environmental Affairs, 'Minister Molewa leads National Consultative Conference on Electronic and Electrical Waste (E-Waste) Management in South Africa' Press Media Release (4 September 2015)<www.environment.gov.za/mediarelease/molewa_e-waste_conference> (hereinafter DEA Press Release).

6 J PUCKETT and T SMITH, Exporting Harm: the High-Tech Trashing of Asia (Basel Action Network (BAN), 2002) 4-10 <www.ban.org/E-Waste/technotrashfinalcomp.pdf >. 
or rudimentary recycling and disposal practices more commonly used in the informal sector, as the formal sector is virtually non-existent in most African countries, with the exception of a few, such as Kenya and South Africa. ${ }^{7}$

Thus, it is not surprising that the increase in the generation of e-waste in Africa has become of immense concern to policy makers in the region. ${ }^{8}$ The scale of the e-waste issue in Africa was recognised by the Conference of the Parties to the Bamako Convention ${ }^{9}$ in early $2018 .{ }^{10}$ Part of the Preamble to the decision on the prevention of electronic hazardous stated:

Aware that the amount of e-waste resulting from household consumption of electronic products is increasing rapidly in Africa and will have a negative impact on health and the environment unless measures are taken, as a matter of urgency, to equip African subregions and States with collection and recycling infrastructure, ${ }^{11}$

At the root of this concern is the issue of how they should regulate the transboundary movement of e-waste within their territories without adversely affecting their citizens' access to much-needed ICT equipment and other derivable socio-economic benefits. This is exacerbated by the ineffectiveness of the various international regulatory measures in curtailing the generation and consequent transboundary movement of such waste streams into developing countries. For instance, the effectiveness of the Basel Convention on the Transboundary Movement of Hazardous Wastes and their Disposal, ${ }^{12}$ the principal multilateral instrument regulating the transboundary movement of hazardous wastes, including e-waste, has been compromised by various loopholes that have been exploited by parties benefitting economically from the waste

$7 \quad$ SbC (n 3) 24-25; and J JIN, 'E-Waste and the Regulatory Commons: A Proposal for the Decentralization of International Environmental Regulation' (2014) 39 Brooklyn Journal of International Law 1251-82, 1256-58.

8 'East Africa countries to cooperate on e-waste management' Xinhua (25 August 2016) $<$ www.kassfm.co.ke/new/index.php/business/item/1664-east-africa-countries-to -cooperate-on-e-waste-management $>$.

9 Bamako Convention on the Ban of the Import into Africa and the Control of Transboundary Movement and Management of Hazardous Wastes within Africa, 30 ILM 773 (Bamako Convention); Nigeria has signed but has not ratified the Bamako Convention.

10 Conference of the Parties to the Bamako Convention on the Ban of the Import into Africa and the Control of Transboundary Movement and Management of Hazardous Wastes within Africa, Second meeting, Abidjan, Côte d'Ivoire 30 January-1 February 2018.

11 Decision 2/6: Prevention of electronic hazardous waste and the import and dumping of end-of-life waste electrical and electronic equipment in Africa, 2018, UNEP/BC/CO/2/6.

12 Basel Convention on the Transboundary Movement of Hazardous Wastes and their Disposal, 22 March 1989, in force 5 May 1992, 1673 UnTs 57. 
trade, including the exportation of e-waste into developing countries under the pretext of re-use or recycling. ${ }^{13}$ The same is applicable in the European Union (EU) where despite the existence of a legal framework prohibiting the export of e-waste to developing nations, ${ }^{14}$ a recent report by the Basel Action Network (BAN) shows that waste brokers/traders are exploiting the loopholes in the enforcement of the legislation to export e-waste to developing countries. ${ }^{15}$ In addition, the status of used EEE, particularly the non-functional equipment, is contentious under the Basel Convention, ${ }^{16}$ and has held up the final adoption of the Technical Guidelines on Transboundary Movements of Electrical and Electronic Waste and Used Electrical and Electronic Equipment. ${ }^{17}$

Various African countries have enacted laws regulating the transboundary movement of e-waste into their territories. ${ }^{18}$ Foremost amongst these countries

13 JIN (n 7) 1260-61; SBC (n 3) above 34-37; JA LONG, 'Protocol on Liability and Compensation for Damage Resulting from the Transboundary Movements of Hazardous Wastes and their Disposal' (1999) Colorado Journal of International Environmental law and Policy 253-261, 254-55; and CW SCHMIDT, 'Environmental Crimes: Profiting the Earth's Expense' (2004) 112 Environmental Health Perspectives 96-103, 101.

14 Directive 2012/19/EU of 4 July 2012 on waste electrical and electronic equipment (WEEE) (recast), [2012] OJL 197/38, annex VI, entered into force on 13 August 2012 (hereinafter WEEE Directive); and Regulation (EC) No 1013/2006 of the European Parliament and of the Council of 14 June 2006 on shipments of waste, OJL 19o, arts 4, 9 and 36 (hereinafter EU Waste Shipment Regulation).

15 Basel Action Network (BAN), Holes in the Circular Economy: WEEE Leakage from Europe (2019) 3 (hereinafter BAN Circular report).

16 Sims Recycling Solution, 'Basel Convention Adopts Technical Guidelines on E-Waste' 16 July $2015<$ http://blog.simsrecycling.com/2015/07/16/basel-convention-adopts-tech nical-guidelines-on-e-waste/>.

17 The Guidelines which have been adopted on an interim basis seek to provide guidance to national authorities (usually environmental agencies and customs) on the transboundary movements of e-waste, and used and discarded EEE that may or may not be e-waste, including the distinction between waste and non-waste under the Basel Convention. See United Nations Environment Programme, Technical guidelines on transboundary movements of electrical and electronic waste and used electrical and electronic equipment, in particular regarding the distinction between waste and non-waste under the Basel Convention, Revised final version(UNEP/CHW.12/5/Add.1/Rev.1), 15 May 2015) 6 para $9<$ http://<www .basel.int/Implementation/Publications/LatestTechnicalGuidelines/tabid/5875 /Default.aspx >. (hereinafter UnEP Technical Guidelines on e-waste and Used EEE).

18 Seegenerallysвс $\left(\mathrm{n}_{3}\right)_{26-28}$. For some specific examples, see Environmental Management and Co-Ordination (E-Waste Management) Regulations, 2013, reg 22 (hereinafter Kenyan E-Waste Management Regulations); National Environmental Management: Waste Act 59 of 2008 of South Africa, as amended by National Environmental Management: Waste Amendment Act No 26 of 2014 (hereinafter SA Waste Act); and Hazardous and Electronic Waste Control and Management Act no 917 of 2016, (hereinafter Ghana Hazardous Wastes Act). 
is Nigeria, which has the unenviable distinction of being one of the preferred, if not the main, destination for e-waste in Africa. ${ }^{19}$ In order to reverse this trend and also address the twin problems of rising e-waste generation and the lack of a formal recycling infrastructure in the country, Nigeria banned the importation of e-waste outright. ${ }^{20}$ However, the effectiveness of the ban is doubtful, as the importation of e-waste into Nigeria is still thriving, as such equipment is 'usually shipped in containers hidden behind working goods, concealed inside a car, or falsely described as personal items.'. ${ }^{21}$ The failure of the ban in curbing the transboundary movement of e-waste into Nigeria necessitates that policy makers must come up with new and innovative means to address this issue.

This article thus explores the regulation of transboundary movement of e-waste into Nigeria, recognising that the current ban on the transboundary movement of e-waste was motivated by the adverse human health and environmental consequences of such imports. However, it argues that the ban is unappreciative of the socio-economic realities and the generally weak regulatory climate in Nigeria, which are factors that drive the transboundary movement of used items, including e-waste, into Nigeria. ${ }^{22}$ In essence, Nigerian policymakers failed to apply a Multi Criteria Analysis (MCA) approach to the regulation of the transboundary movement of e-waste. The application of the MCA approach, which allows for consideration of different solutions and alternatives based on cost and benefits, ${ }^{23}$ would have resulted in a situation whereby the full range of the socio-economic, environmental and human health and regulatory impacts of the e-waste imports would have been taken into consideration by Nigerian policymakers. Unsurprisingly, such nonapplication has resulted in a situation whereby high volumes of e-waste are

\section{$19 \quad$ Ibid 21 and 38.}

20 National Environmental (Electrical/Electronics Sector) Regulations S.I. No. 23 of 2011, reg 34(2). (hereinafter EE E Sector Regulations).

21 TT OLAIYA, 'Inside the toxic graveyard of Lagos' The Guardian, 17 March $2017<\mathrm{https} / / /$ guardian.ng/features/inside-the-toxic-graveyard-of-lagos/>. See also Basel Convention Coordinating Centre for the African Region (BсCC Africa) and United Nations University (UNU), Assessing Import of Used Electrical and Electronic Equipment into Nigeria: Person in the Port Project (2018) <https://collections.unu.edu/eserv/UNU:6349/PiP_Report.pdf> (hereinafter PiP report).

22 See recent ban on used items in Nigeria, 'FG bans importation of 25 items' News Express, 6 January 2017 <https://www.newsexpressngr.com/news/32929-FG-bans-importation -of-25-items-FULLLIST?pr=35461\&lang=en>; and 'Govt issues fresh ban on importation of Tokunbo tyres' The Nigerian Voice, 10 May 2016 <https://www.thenigerianvoice.com /news/216533/govt-issues-fresh-ban-on-importation-of-tokunbo-tyres.html>.

23 Secretariat of United Nations Framework Convention on Climate Change (UnfCCC), 'Multicriteria Analysis (MCA)' <http://unfccc.int/files/adaptation/methodologies_for /vulnerability_and_adaptation/application/pdf /multicriteria_analysis_mca_pdf.pdf >. 
still being imported, albeit illegally, into Nigeria, with adverse environmental and human health consequences. The article therefore argues for a shift in policy from outright prohibition of the import of e-waste into Nigeria to the regulation and sustainable management of such importation. In support of this argument, it focuses on the current approach in the Republic of Ghana with regard to the importation of e-waste. The focus on Ghana's approach to the regulation of importation of e-waste is relevant to policymakers in Nigeria as the former is arguably the second highest recipient of e-waste imports in subSaharan Africa, ${ }^{24}$ and has experienced its fair share of the environmental and health problems arising from such import. ${ }^{25}$ The article begins by examining the legal frameworks for the transboundary movement of e-waste into Nigeria. This is followed by a discussion of the mostly socio-economic and regulatory factors that have impeded the efficient enforcement of these legal frameworks. Flowing from this, the article argues for a policy shift in the regulation of the transboundary movement of e-waste into Nigeria, while drawing comparative lessons from Ghana's experience in this regard. The article concludes by stressing the importance of a policy shift concerning the transboundary movement of e-waste into Nigeria.

Legal Frameworks for the Control of Transboundary Movement of E-waste into Nigeria

Nigeria has had an unsavoury history with the transboundary movement of hazardous wastes into its territory, and this has likely influenced its strict legislative response to the importation of hazardous wastes including e-waste. For instance, in June 1988, over 3,500 tonnes of toxic/harmful wastes originating from Italy were dumped in Koko, a coastal town situated in the Delta State of Nigeria. The attendant public outcry due to the adverse environmental and human rights consequences of the dumping galvanized the Federal Government into enacting the Harmful Waste (Special Criminal Provisions etc.) Act, on 30 November $1988 .{ }^{26}$ The Act, although dealing with a specific issue, was the first explicit environmental legislation enacted in Nigeria. Likewise, a similar uproar that was generated when the news broke about the

24 SвC (n 3) 21. (finding that Nigeria and Ghana are the main import hubs for used EEE into Africa).

25 Greenpeace, 'Poisoning the poor-Electronic Waste in Ghana' 5 August 2008; <www .greenpeace.org/denmark/Global/denmark/p2/other/report/2008/poisoning-the-poor -electroni.pdf $>$.

26 Harmful Waste (Special Criminal Provisions etc.) Act Cap Hı Laws of the Federation of Nigeria 2004. (hereinafter HWA). 
massive shipment of container loads of e-waste into Nigeria in 2010, influenced the adoption of the National Environmental (Electrical/Electronics Sector) Regulations in 2011. ${ }^{27}$ It is instructive to examine these legal frameworks in detail.

\subsection{The Harmful Waste Act}

The Harmful Waste Act (HWA) 2004 was basically enacted to prevent a reoccurrence of transboundary movement and dumping of hazardous wastes in Nigeria, as evidenced by the Koko toxic waste incident. It prohibits all activities relating to the purchase, sale, importation, transit, transportation, deposit or storage of harmful waste without lawful authority. ${ }^{28}$ Criminal liability under the Act is strict, ${ }^{29}$ and infringements are punishable with heavy penalties, including life imprisonment. ${ }^{30}$ The term 'harmful waste' is defined under the Act to mean 'any injurious, poisonous, toxic or noxious substance and, in particular, includes nuclear waste emitting any radioactive substance if the waste is in such quantity,... as to subject any person to the risk of death, fatal injury, or incurable impairment of physical and mental health. ${ }^{31}$ This omnibus definition has been criticized as being too long, ambiguous and unclear. ${ }^{32}$ However, the definition has made it possible for the provisions of the Act to cover not only known pollutants such as nuclear wastes and other hazardous wastes emanating from industrial activities, but also emerging pollutants such as e-waste. ${ }^{33}$ Regarding the latter, it is acknowledged that e-waste was obviously not in the contemplation of the framers of the Act, as it only started to emerge as an environmental and human health menace during the late 1990s in Nigeria and later ballooned with the rapid ICT transformation fuelled by drastic policy changes within the ICT sector in the early 2000 .

The application of the Act to the regulation of transboundary movement of e-wastes into Nigeria rests on two premises. First, the above definition of harmful waste reflects the chemical characteristics of e-waste which caused

27 EEE Sector Regulations (n 20).

28 HWA (n 26) s 1.

29 Ibid ss 1 and 8. But see ss 5 (accessories after the fact), and 7 (liability of corporate officers).

30 For offences under ss $1^{-} 5$ of the HWA, any person convicted is liable to life imprisonment and shall forfeit any carrier used in the transportation or importation of the harmful waste, and any land on which such waste was deposited or dumped. For attempt, the offender shall be liable only to life imprisonment; see s 8(1).

31 Ibid s 15.

32 T OKONKWO, The Law of Environmental Liability (Afrique Environmental Development and Education 2003) 5 .

33 EP AMECHI, 'Environmental Pollution and Human Rights: Some Reflections on the Linkages and the Need for Effective Enforcement of Environmental Regulations in Nigeria' (2012/11) 18 (1) The Nigerian Journal of Contemporary Law 93-129 116. 
such wastes to be regarded as hazardous wastes under the Basel Convention. ${ }^{34}$ Secondly, by the time that the saga pertaining to the container loads of e-waste broke out in 2010, e-waste was already being designated as hazardous waste under the National Environmental (Sanitation and Wastes Control) Regulations. ${ }^{35}$ The Regulations explicitly listed types of hazardous waste to include 'End-of-Life waste of House electrical and electronic appliances and residues arising from the incineration of the same. ${ }^{36}$ Such designation is important, as only a hazardous waste can be classified as harmful waste under the Act, although the term 'hazardous waste' is wider in scope than the term 'harmful waste' under Nigerian law. ${ }^{37}$ In such a scenario, it can be argued that the Act is linked to the Sanitation and Wastes Control Regulations. This perhaps explains why the Act was used as the principal instrument for justifying the measures adopted by the National Environmental Standards and Regulations Enforcement Agency (NESREA) in tackling the transboundary movement of e-waste prior to the adoption of specific EEE Regulations in 2011. ${ }^{38}$

A principal criticism of the Act is that apart from the seizure and repatriation of containers laden with e-waste, ${ }^{39}$ there has not been much enforcement of the Act's provisions, including prosecution, which would serve as deterrence to would-be importers of e-waste. Perhaps this lacuna is due to the fact that Act was not ab initio adopted for the regulation of e-waste. Consequently, the enforcement of its deterrence measures, such as life imprisonment

34 Basel Convention (n 12) art 1 (a) - (b) and annex viII.

35 S.I. 29 of 2009. (hereinafter Sanitation and Wastes Control Regulations).

36 Ibid Schedule XIII, para c.

37 Reg 106 of the Sanitation and Wastes Control Regulations broadly define the term 'hazardous waste' to mean 'any waste or combinations of wastes that ... poses a substantial danger, now or in the future, to human, plant or animal life .... This is unlike the more restrictive definition of the term 'harmful waste' under the HWA that only stipulate '... as to subject any person to the risk of death, fatal injury, or incurable impairment of physical and mental health'. In essence, the former regulates waste or combination of wastes that poses danger to human, plant and animal life, while the latter is restricted to only waste that poses danger to human mental and physical health.

38 For instance, the seizure and repatriation of the e-waste laden containers back to the port of origin can be justified under the HWA. See HWA (n 26) ss 10(1)(d) and 11(5).

39 For instances of such repatriation, see LC ANUKAM, E-Waste Control: The Nigeria's Experience,Conferencepaperpresentedatthe2ndINTERPOLEnvironmentalCompliance and Enforcement Conference, INTERPOL Complex, Singapore, 16-18 November, 2015, 14 <https://<www.interpol.int/es/Media/Files/Crime-areas/Environmental-crime/Mee tings/2nd-INTERPOL-Environmental-Compliance-andEnforcement-Events /Presentations/Waste-Management-\%E2\%80\%93-Day-2/E-Waste-Control,-TheNigeria\% E2\%80\%99s-Experience-Lawrence-Chidi-Anukam,-Director-General,-CEO-NESREA>. 
and forfeiture of any carrier used in the transportation or importation of e-waste into Nigeria, ${ }^{40}$ might be considered too harsh for anyone violating its provisions. ${ }^{41}$ Indeed, e-waste has its socio-economic advantages in terms of providing employment. It is thus not likely to be viewed in the same light as nuclear wastes, incinerator wastes or other wastes similar to that associated with the Koko toxic waste incident, which the HWA primarily seeks to regulate. Another criticism of the Act is that the current practice of seizing and repatriating e-waste to the country of origin appears to be effective only against container-laden imports, and not against imports by means of used cars and trucks. The latter has now been identified as the main source of transboundary movement of e-waste into Nigeria. ${ }^{42}$

\subsection{The National Environmental (Electrical/Electronics Sector) Regulations}

The lacunae evident in using the provisions of the HWA in regulating the transboundary movement of e-waste into Nigeria necessitate the adoption of a specific regulation dealing with the imports of such waste into Nigeria. NESREA as the agency mandated with enforcing all environmental legislation together with the checking and regulating e-waste trafficking, ${ }^{43}$ responded by adopting the EEE Sector Regulations. ${ }^{44}$ The Regulations are not only concerned with regulating the transboundary movement of e-waste, but function as the principal instrument through which Nigeria seeks to address environmental pollution arising from all operations and ancillary activities of the EEE sector in the country. 45 The Regulations are based on a life-cycle approach and cover all aspects of the EEE sector from cradle to grave. ${ }^{46}$ They are also anchored on the principles of reduce, repair, recover, recycle and re-use of EEE ( $5 \mathrm{Rs})$ as the primary drivers of the sector. ${ }^{47}$ Pursuant to this, all new and used EEE imported into the country must be functional, and all importers of such EEE must

\footnotetext{
40 HWA (n 26) s 6 (a).

41 It appears that NESREA has resorted to the imposition of administrative fines instead of life imprisonment and forfeiture of carrier used in the importation of e-waste. Although the Act never provided for the option of a fine, payment of such administrative fines is provided under paragraph 2 (g) of Schedule II to the EEE Sector Regulations.

42 PiP report (n 21) 30.

43 The National Environmental Standards and Regulations Enforcement Agency (Establishment) Act No 25 of 2007, s 7 (a) and (h), (Hereinafter NesreA Act).

44 EEE Sector Regulations, (n 20).

45 Ibid reg $1(1)$.

$46 \quad$ Ibid $\operatorname{reg} 1(2)$.

$47 \quad$ Ibid reg $1(3)$.
} 
register with NESREA. ${ }^{48}$ In addition, all importers, manufacturers, distributors, retailers and assemblers of EEE products shall subscribe to an Extended Producer Responsibility Programme (EPR), including the buy-back scheme, ${ }^{49}$ and the payment of an administrative cost to promote environmentally sound management (ESM) of e-waste. ${ }^{50}$

E-waste is defined under the Regulations to mean 'Waste Electrical Electronic Equipment (WEEE) including old, end-of-life (eol) or discarded electrical/electronic appliances using electricity'. ${ }^{51}$ The implication is that any EEE, whether used or new, that falls within this definition is considered as e-waste in Nigeria, irrespective of the potential for re-use after repair or refurbishment. The wider definition accords with the provisions of art $1(b)$ of the Basel Convention, which 'incorporates domestic law such that material regarded as a hazardous waste in one country but not another is defined as hazardous waste under the Convention.52 This is further supported by the UNEP Technical Guidelines on Transboundary Movement of e-waste and Used EEE, which recognize the right of state parties to the Basel Convention to define or consider any used EEE as waste under the provisions of their legislation..$^{53}$ Specifically on the transboundary movement of e-waste into Nigeria, the Regulations prohibit the import of end-of-life, unusable or unserviceable EEE. ${ }^{44}$ It is therefore an offence punishable by a fine or imprisonment or both to undertake such activities. ${ }^{55}$ In addition, any imported e-waste shall be sent back to the port of origin and any vessel used in the importation shall be forfeited to the Nigerian Government. ${ }^{56}$ NESREA is also authorized to impose administrative punitive fines on the carrier of e-waste or used EEE mixed with e-waste. ${ }^{57}$

\footnotetext{
48 Ibid 2 and 3 .

$49 \operatorname{Ibid} 11(1)$.

50 Ibid reg $11(4)(d)$. This only applies to importers of new and used EEE as part of EPR.

51 Ibid 68

52 UNEP Technical Guidelines on e-waste and Used EEE (n 17) 23.

53 Ibid paras 27 and 30; see also EU Waste Shipment Regulation (n 14) art 9.

54 EEE Sector Regulations (n 20) reg 34(2) see also Schedule II, para 2(d) and(i) of the Regulations.

55 Ibid regs $61(1)(a), 67(1)$ and $67(3)$; for the provisions prohibiting and criminalizing the importation of cathode ray tubes, see regs 34(3), 61(1)(c) and 67(2).

$56 \quad$ EEE Sector Regulations (n 2o) Schedule II, para 2 (f) and (g).

57 Ibid para $2(\mathrm{~h})$.
} 


\section{Factors Limiting the Effectiveness of E-waste Legal Frameworks on Transboundary Movement into Nigeria}

It is apparent from the preceding discussion that adequate legal frameworks exist for the control of the transboundary movement of e-waste into Nigeria. Indeed, as argued above, whatever inadequacy may have plagued the effective enforcement of the HWA, particularly the penalty provisions, has been addressed by the adoption of the NESREA EEE Sector Regulations. The implication is that there should be a firmer control of the transboundary movement of e-waste into Nigeria. Admittedly, stronger enforcement by the Nigerian government through NESREA has reversed the state of affairs prior to 2010 when containers laden with e-waste were routinely trafficked into the country. ${ }^{58}$ However, whatever hope that this would translate to a drastic reduction in the transboundary movement of e-waste into Nigeria was dashed by the finding of the Person in the Port (PiP) project report that in 2015 and 2016, at least $70 \%$ or 41,500 tonnes of the used EEE reaching Lagos each year arrived inside used vehicles destined for Nigeria's auto market. ${ }^{59}$ The report further finds that a limited functionality test on these imported used EEE (containerized or inside used vehicles) indicated that at least about 15,400 tonnes are e-waste. ${ }^{60}$ In essence, the gains made by the reduction of import of e-waste through containers, has been reversed by the fact that thousands of tonnes of e-waste are still being shipped illegally to Nigeria, albeit inside used vehicles. ${ }^{61}$

Apart from the gloomy statistics presented in the PiP report, which admits of data uncertainty of the actual magnitude of e-waste imports in containers and used vehicles, ${ }^{62}$ a visit to the marketing hubs for imported used EEE such

58 SвC (n 3) 21; ANUKAM (n 39) 14; and PiP report (n 21) 28-29. (The PiP report, co-authored by the Basel Convention Coordinating Centre for Africa (вСCC Africa) and the Sustainable Cycles (SCYCLE) Programme of United Nations University Vice-Rectorate in Europe, shows that only about 18,300 tonnes or $30 \%$ of used EEE reaching Lagos ports each year arrived in shipping containers).

59 PiP report (n 21) 26-27.

6 o Ibid $47-48$.

61 The Report, while noting that the overall volumes of used EEE in 2016 and 2016, can be assumed to be lower than those of previous years, attributed the trend to other factors besides enforcement of legislation such as the economic decline in the past years which decreased the buying power of Nigerian people, and effectively their demand for used EEE, ibid $55^{-56}$.

62 Ibid 31-33, 43-44 and 56; see also SBC (n 3 ) 37-38 (also admitting that it is challenging to find reliable quantitative figures on the flows of used and end-of-life EEE from Europe to West Africa). 
as Westminster market, Alaba market, Lawanson market, Ikeja computer village and to some extent, Ladipo market, would reveal the alarming magnitude of the transboundary movement of e-waste into Nigeria through used vehicles. Although a very high percentage of the imported non-functional used EEE (e-waste) are repairable or their functional components used as spare parts due to the high skill level of the Nigeria's refurbishing sector, ${ }^{63}$ the discarded components end up in the municipal dump sites with the attendant environmental and human health consequences. The negative environmental and human health consequences are magnified by the fact that it is still 'a common observation in Nigeria to find the management strategies employed to special (hazardous) waste like WEEE as the same with general solid waste management practices in the collection, intermediate storage, transporting and final disposal. ${ }^{64}$

Flowing from this, it can be argued that the continuing transboundary movement of e-waste into Nigeria is not due to lack of a national regulatory framework, but rather due to inadequate enforcement of the laws prohibiting the importation of such waste into Nigeria. ${ }^{65}$ This has created a state of affairs that is being exploited particularly by foreign waste brokers/traders including those from the EU which, as earlier noted, specifically prohibited such export to developing countries such as Nigeria. ${ }^{66}$ The inadequate enforcement is due to a combination of various inter-related factors as set out below.

\subsection{Rapid Ict Transformation in Nigeria}

Nigeria, like other African countries, has been undergoing rapid ICT transformation in recent years. ${ }^{67}$ The transformation is boosted by drastic policy changes within the sector introduced at the on-set of the present democratic conditions in the country, including privatization of the hitherto mostly publicly-operated ICT networks, and the development of new technologies that are ideal for the Nigerian environment. ${ }^{68}$ The rapid pace of the ICT transformation in Nigeria is aptly described by Obaje as follows:

\footnotetext{
63 Ibid 5 .

64 O OKORHI, EE OKEREKA, CO AKHIMIE and KK ENEKWENCHI, 'Frontiers and Prospects for Recycling Waste Electrical and Electronic Equipment (WEEE) in Nigeria' (2017) 21 (7) J. Appl. Sci. Environ. Management, 1382, 1382 (footnote from original omitted).

65 PiP report (n 21) 57.

66 For instance, the Basel Action Network (BAN) traced the illegal export of three (3) units of non-functional used EEE from the United Kingdom (UK) to Nigeria. It further indicated that the units which were fitted with tracking devices were dropped in government approved e-waste recycling centres in various locations within the UK. BAN Circular report (n 15) 89-101.

67 SBC (n 3$) 19$.

68 Ibid 15.
} 
In 1999, only 35,000 Nigerians had access to mobile telephone lines but by the end of 2004, the numbers increased to over 9.1 million ... According to NCC (2013), Nigerian teledensity was $75.17 \%$ with subscribers' statistics of 105,239,815 in August 2012. In June 2013, Nigerian teledensity rose to $85.97 \%$ with $120,362,218$ subscribers. On the other hand, the Nigerian Guardian (2013) reported that the installed capacity of all telecommunication providers in Nigeria was 226.6 million in January 2013 while the values rose to 234.1 million in July 2013. In addition, there is stupendous increase in Internet connectivity in Nigeria today ... ${ }^{69}$

In view of the scenario described above and considering that the per capita use of EEE, particularly ICT equipment in Nigeria, is low in comparison with other countries outside Africa, ${ }^{70}$ it is not surprising that Nigerian citizens are seeking affordable access to ICT by patronising the obviously cheaper used EEE. Such reliance on used EEE in bridging this digital divide, is principally influenced by the inability of the average Nigerian to afford new EEE, compared with the situation in developed countries. ${ }^{71}$ Nevertheless, it has reportedly enabled better access to lower-priced ICT equipment in Nigeria, as well as a level of ICT penetration that has been rated to be as high as those of more-developed African countries such as Morocco and South Africa. ${ }^{72}$ Affordability is widely recognized as the main determining factor in the preference for used $\mathrm{EEE}$, as reports have shown that Nigeria is a country with a high level of poverty. ${ }^{73}$ However, it is not the sole determining factor, as the quest for brand names and the issue of durability of imported used EEE over new EEE cannot be dismissed. Indeed, Nigerians perceive used EEE from either Europe or the United States to have 'higher quality and durability as compared with lower priced new equipment imported from other regions. ${ }^{74}$

The increased ICT penetration in Nigeria through used EEE encourages a boom in trade in used EEE within Nigeria, and consequently, an increase in

69 SO OBAJE, 'Electronic Waste Scenario in Nigeria: Issues, Problems and Solutions' (2013) 2 (11) International Journal of Engineering Science Invention, 31-36 32.

$70 \quad$ SBC $\left(\mathrm{n}_{3}\right) 22$.

71 OBAJE (n 69) 32-33 and OLAIYA (n 21).

72 SBC (n 3) 22-23.

73 For instance, see the World Bank, Poverty and Equity Brief: Sub-Saharan Africa-Nigeria (April 2018) <http://databank.worldbank.org/data/download/poverty/33EFo3BB-9722 -4AE2-ABC7-AA2972D68AFE/Archives-2018/Global_POVEQ_NGA.pdf $>$; and the World Data Lab, World Poverty Clock: Nigeria (June 2018) <https://worldpoverty.io/>.

74 Ibid 39; see also OLAIYA (n 21); FC ERIKSEN, IA KINBAJO, I SORBYE and M VEE, 'Nigeria: Investigation-Inside Nigeria's Toxic "Tokunbo" Trade' Premium Times, 20 December 2016 <https://<www.premiumtimesng.com/news/headlines/218472-inves tigation-inside-nigerias-toxic-tokunbo-trade.html>. 
transboundary movement of e-waste into Nigeria by foreign waste brokers/ traders and Nigerians seeking to take advantage of the boom despite the ban on the importation of e-waste. ${ }^{75}$ It should be noted that the boom in used EEE trade in Nigeria has led a situation whereby such equipment, including e-waste, have 'achieved prices far above their intrinsic material value' in the exporting countries. ${ }^{76}$ This fact is not lost on especially foreign waste brokers/traders who are mainly seeking to dispose of their e-waste in a more cost-effective and profitable manner. ${ }^{77}$ This attitude was aptly captured in a statement attributed to Craig Lorch, the vice-president of Total Reclaim, a Seattle-based company providing domestic recycling for cathode ray tubes:

Right now, the economics of electronics recycling clearly prefers export over managing the material in the U.S. Every day we must make the choice between spending money to disassemble and manage the material here or simply load it into a shipping container and sell it offshore. Why would a good business person allow spending 3 to 4 dollars to disassemble and handle material domestically when the same material can be sold offshore for 3 bucks. It's a 6 dollar swing — that's a make or break difference for a recycler. ${ }^{78}$

Thus, it is apparent that the attitude of the foreign e-waste brokers/traders which ensured the constant flow of e-waste from developed countries including the EU to Nigeria is driven by simple economics. This is exacerbated by the generally weak enforcement regime with regard to the importation of e-waste in Nigeria (see below). Giving this scenario, it is not unexpected that the aforementioned group of people would take advantage of any loophole in the laws or enforcement regime to import e-waste into Nigeria mostly under the guise of 'used EEE', 'second-hand goods', 'personal effects' or 'household goods. ${ }^{79}$ This is more evident in the current popular practice of importing e-waste into Nigeria through used vehicles. It should be noted that this import route not only lacked thorough assessment until the PiP report, ${ }^{80}$ but also, has not been the subject of much inspection and control by the regulatory agencies such as NESREA

75 Ibid 35-36. See also PUCKETT and SMITH (n 6).

76 SBC (n 3$) 10$ and 36.

77 PUCKETT and SMITH (n 6) 8 and 11; and BAN Circular report (n 15) 1 and 24.

78 Quoted in SBC (n 3) 10.

79 SвC (n 3) 37. See also PiP report (n 21) 43-44 and 57; and Greenpeace, 'Where Does E-Waste End Up?' 24 February 2009 <www.greenpeace.org/international/en/campaigns /toxics/electronics/the-ewaste-problem/where-does-e-waste-end-up/>. 
and the Nigerian Customs Service. ${ }^{81}$ This is unlike the used EEE import route through containers, which is subject to Environmental Import Clearance as a prerequisite to be the issuance of form M by the NCs. ${ }^{82}$ Arguably, the charge imposed by NESREA for the environmental import clearance for used EEE, ${ }^{83}$ may have inadvertently encouraged importers to resort to the used vehicle route or false declaration of their containers as merely 'used' items. ${ }^{84}$

\subsection{Socio-Economic Benefits of the Transnational Trade in E-waste in Nigeria}

Allied to the rapid ICT transformation is the fact that many people's livelihoods are dependent on the transboundary movement into Nigeria of e-waste. For a country with high unemployment rates and low per capita income, this is an important factor in understanding the underlying causes of regulatory failure relating to the transboundary movement of e-waste. ${ }^{85}$ This is because it is generally more challenging and difficult to enforce laws against popular commercial interests, which is what the trade in e-waste has become in Nigeria. Indeed, due to the socio-economic benefits of the transnational trade in used EEE, most Nigerians see e-waste as a resource rather than a waste. ${ }^{86}$ Presently, Nigerians are involved in the importation of used EEE which most times is mixed with e-waste, ${ }^{87}$ including Nigerian immigrants 'who create small trading businesses within Europe to serve European-African trade routes.' ${ }^{\prime} 8$

81 Ibid 49 and 57. See also Catena, 'Importation of used items in Nigeria', 13 November 2015 $<$ http://<www.exports-to-nigeria.com/en/news/importation\%20of\%2oused\%2oitems >.

82 See the National Environmental Standards and Regulations Enforcement Agency (NESREA), 'Requirements for Nesrea Environmental Import Clearance and Certification of Importers of Used Electrical Electronic Equipment' <http://<www.nesrea.gov.ng/pub lications-downloads/requirements-for-nesrea-environmental-import-clearance-and -certification-of-importers-of-used-electrical-electronic-equipment/> and the National Environmental Standards and Regulations Enforcement Agency (NEsREA), 'Categories of Items that Require Environmental Import Clearance’ <http://<www.nesrea.gov.ng/wp -content/uploads/2017/og/Environmental_Import_Clearance_Item_Categories.pdf $>$.

83 The clearance is only issued subject to the importer paying the registration fee of 150,000 Naira (approx. US\$ 400) and subsequently being issued a Used EEE Import Certificate. The registration is renewed annually for 50,000 Naira (approx. US\$ 138). See PiP report (n 21) 49; and 'Clearing Agents Resist NESREA Charges on Imported Vehicles at Ports', Shipping Position, 7 December $2015<$ http://shippingposition.com.ng/autoport /clearing-agents-resist-nesrea-charges-on-imported-vehicle-at-ports>.

$84 \quad$ PiP report (n 21) 49.

85 SвC (n 3) 19-20.

86 Eriksen et al ( $\mathrm{n} 74)$.

87 SBC (n 3) 35-40; PiP report (n 21) 8; and EeE Sector regulation (n 20) schedule II, para 1.2.

88 Ibid 36 . See also J BURRELL, 'What environmentalists get wrong about e-waste in West Africa' Berkeley Blog, 1 September 2016<http://blogs.berkeley.edu/2016/og/o1/what-envi ronmentalists-get-wrong-about-e-waste-in-west-africa/> . 
They are also actively if not solely involved in the sale, repair, refurbishing, dismantling, or recycling of e-waste within the country. ${ }^{89}$ The Basel Convention E-waste African Programme observed the presence of a wellorganized and formal refurbishing sector in Nigeria that provides income to more than 30,000 people. ${ }^{90}$ It further noted that in Lagos alone, the Ikeja Computer Village and Alaba International Market, have achieved high levels of professionalism and gained regional importance by supplying refurbished equipment not only to Nigerian households, but also to other West and Central African countries'. ${ }^{91}$ Equally worthy of note in the report by the Basel Convention E-waste African Programme is the finding that aforementioned refurbishing clusters boast about ' 5,500 small enterprises with around 15,000 technicians and sales personnel. Many of these workers have a comparably high education and most of them went through a sector-specific apprenticeship system lasting between two and five years. ${ }^{92}$ This system is replicated, albeit to a lesser extent, in refurbishing clusters that are springing up in major cities throughout Nigeria.

The socio-economic benefits also extend to the recyclers who apply simple or informal recycling processes such as manual dismantling with simple tools and open burning to recover metals, and mostly 'prioritize reclamation of the valuable components and substances from the recycling process'. ${ }^{93}$ Although findings have shown the informal recycling process is mostly undertaken by poor internal migrants from the rural parts of Northern Nigeria, it is still one of the few economic activities they can engage in without prior training or investment. ${ }^{94}$ In any event, it enables them to have regular access to cash as 'the revenues from one day's work immediately materialize when the recycling products are sold to one of the local middlemen'. ${ }^{95}$

\subsection{Weak E-waste Import Enforcement Regime}

The enforcement of import policies has always been problematic in Nigeria, and is magnified in instances when the regulated product is in high demand amongst the populace, encouraging a boom that importers are always interested in exploiting. Specifically, concerning the enforcement of the ban on transboundary movement of e-waste into Nigeria, it appears that the regulatory agencies (NESREA and NCS) have been overwhelmed by the sheer volume

$\begin{array}{ll}89 & \text { Ibid 29-32 and 37-38. } \\ 90 & \text { Ibid 30. } \\ 91 & \text { Ibid. } \\ 92 & \text { Ibid. } \\ 93 & \text { Ibid 24. } \\ 94 & \text { Ibid 31. } \\ 95 & \text { Ibid 31. }\end{array}$


of e-waste coming into the country, and decided to focus on regulating the importation of such waste coming in containers. ${ }^{96}$ Even with that relatively limited focus, the PiP report finds evidence of inadequate enforcement of regulations regarding the transboundary movement of containerized e-waste into Nigeria. ${ }^{97}$ Such a finding is not surprising, as prior to the report, the Lagos State Coordinator of NESREA had admitted that 'because of the volume of imports into Nigeria, his agency only does e-waste inspections on imported vessels when it is tipped off by international organisations like Interpol. Significantly other containers about which the agency is not tipped off are not searched.'98

\section{Policy Shift in the Regulation of the Transboundary Movement of E-waste in Nigeria}

\subsection{Imperative of a Policy Shift in Nigeria}

The preceding section discussed the interrelated factors that encouraged the transboundary movement of e-waste into Nigeria. Ordinarily, considering the negative human health and environmental consequences of such transboundary movement, the simplest solution would have been to 'legislate' the problem away by banning the transboundary movement of e-waste as Nigeria sought to do through the adoption of particularly the EEE Sector Regulations. However, the same factors that encouraged a boom in trade in used EEE and ultimately the transboundary movement of e-waste into Nigeria, have made such regulatory measures to be counterproductive and thus prone to failure. Interestingly, these factors were in existence prior to the adoption of the EEE Sector Regulations that banned the importation of e-waste into the country. Thus, it can be argued that Nigerian policymakers did not take cognizance of these factors in formulating the present regulatory policy on the transboundary movement of e-waste into the country. They were rather motivated principally by what has been described as 'misguided environmental activism that has been influential all the way up to the United ...[Nation]s Environment[al] Program and Interpol. ${ }^{99}$

In essence, the decision to ban the transboundary movement of e-waste into Nigeria was not based on the Multicriteria Analysis approach in the environmental decision-making process. ${ }^{100}$ If the approach was ever taken

\footnotetext{
96 ERIKSEN et al ( $\mathrm{n} 74)$.

$97 \quad$ SBC (n 3) 45, 49 and 57.

98 ERIKSEN et al ( $\mathrm{n} 74)$.

99 BURRELL (n 88).

$100 \quad$ UNFCCC (n 23).
} 
into consideration by Nigerian policymakers, it would have shown that for a country with increasing ICT needs, low socio-economic standards and a weak enforcement regime, a ban on the importation of e-waste might not be efficient from a regulatory viewpoint, considering the socio-economic potentials offered by such equipment after repair, ${ }^{101}$ refurbishment, or the re-use of functional components. Understandably, if Nigeria was an African country with higher socio-economic standards, such as South Africa and Morocco, such a ban might be more effective, as findings have indicated that there is a lower level import of e-waste within these countries, as there is less reliance on used EEE. ${ }^{102}$ It is noted however, that due to its recycling capacity, South Africa allows the importation of e-waste. ${ }^{103}$ Further, besides the findings of the PiP report, the consequences of the neglect to consider the MCA approach in banning the transboundary movement of e-waste in Nigeria can be illustrated by the failure of the existing ban on the importation of other used items such as used clothes (popularly called 'okirika', or 'bend-down boutiques', as the clothes are generally laid out on the ground) and tyres, which led to lucrative smuggling rackets in such products. ${ }^{104}$ Unsurprisingly, the same issues of affordability, brand names and durability, socio-economic benefits and a weak enforcement regime that promote the illegal transboundary movement of e-wastes into Nigeria are equally responsible for the continuing illegal import of these banned used items. ${ }^{105}$ As pointed out by Akande, 'the import and sale of used clothes are illegal in Nigeria, but visit the major hubs of

101 Re-use means the process of 'using again used equipment or a functional component from used equipment in the same or a similar function, possibly after refurbishment, repair or upgrading'. See SBC $\left(\mathrm{n}_{3}\right) 8$.

102 SBC (n 3) 21.

103 E-waste is recognized as a priority waste in South Africa, and thus, its importation, recycling, or disposal is regulated under the Waste Act. See SA Waste Act (n 18) ss 14 and 15 (as amended by National Environmental Management: Waste Amendment Act No 26 of 2014).

104 For the history and failure of the ban on used clothes in Nigeria, see generally, ED Ogbonnaya, O Udevi and CC Uwakwe, 'Post-Civil War Trade in Second-Hand Clothing in Igboland' (2017) 3 (3) Igwebuike: An African Journal of Arts and Humanities 29-41.

105 Ibid 30-33. See also M ABUBAKAR, J OLUYEMI, R ABDULATEEF, A EMMANUEL, J ADEGOKE and TW Motolani, 'Imperialism and Loss of Identity in Second Hand Clothes: The Nigerian Okrika Experience' (2018) 9(1) Journal of Language, Technology and Entrepreneurship in Africa 151-172 156-59; Segun AKANDE, 'Akube: Nigeria's used clothes trade is benefiting from a shrinking economy' Pulse News, 1 August $2017<$ https://<www.pulse.ng/gist/akube-nigerias-used-clothes-trade-is-benefiting-from -a-shrinking-economy-id7080722.html>; Mohammed ADOW and Chris ARSENAULT, 'Contraband clothes dominate Nigeria's market' AlJazeerah 25 August $2012<$ https: / <www .aljazeera.com/indepth/features/2012/08/2012824143154573858.html>; and Mohammed ADOW, 'Nigerian second-hand clothes industry thrives' Al Jazeera 3 September 2012 <https://<www.aljazeera.com/blogs/africa/2012/08/33766.html>. 
used clothes in Lagos, Kotangora, Yaba, Aswani on Monday or Friday, and you will see any ban only exists on year-old sheets of paper.'106 Thus, the Federal Government should have considered the socio-economic and regulatory factors that led to the failure of the ban on the import of other used items before taking the present policy position on the imports of e-waste.

Based on the failure of the ban in stopping the transboundary movement of e-waste into Nigeria, this article argues for a shift in policy that allows the transboundary movement of e-waste into the country. Specifically, it proposes that Nigeria should seek to maximize the socio-economic benefits offered by such trade, while minimizing the negative environmental and human health impacts. Crucial to achieving this is the recognition by policymakers in Nigeria that e-waste is not just 'waste', but a resource to the importers, repairers, refurbishers and recyclers. ${ }^{107}$ Regarding recycling, such recognition is crucial in creating the enabling regulatory environment that would spur the establishment of formal recycling infrastructure with the attendant environmental and socioeconomic benefits. ${ }^{108}$ Findings have shown that when formalized, recycling literally could be a 'goldmine' for Nigeria, as there are reportedly 'about 250 kilogrammes of gold in one million phones, ${ }^{109}$ while the market potentials for 'e-waste recycling are enormous, as the annual growth rate of WEEE in Nigeria is put at $10 \%$ in the volume of waste generated.' ${ }^{110}$ Likewise, when formalized recycling infrastructure is present, e-waste is not usually an environmental problem. ${ }^{111}$ However, as aptly pointed out by a Director of Compliance at Dell, ${ }^{112}$ maintaining a ban on transboundary movement of e-waste into African countries would have the effect of discouraging investments on formal recycling infrastructure, as the e-waste generated within the country may not be within

106 AKANDE (n 105).

107 K KHALEMA, 'E-Waste: South Africa's Next Gold Rush?' Waste Management World, 14 August $2013<$ https://waste-management-world.com/a/e-waste-south-africas-nxt -gold-rush>; and Holly YOUNG, 'Dell e-waste director: don't ban secondhand computers' The Guardian, 2 July 2014 <www.theguardian.com/global-development-professionals -network/2014/jul/o3/e-waste-computers-dell-recycles.

108 'E-Waste Threat Tackled Head-On' Green I.T., December 2013<www.cloudhostingmaga zine.co.uk/Articles/index.php? $\mathrm{mag}=$ Green\&page $=$ compDetails\&link $=3100>$.

109 OLAIYA (n 22) citing Oladele OSIBANJO, former professor of analytical and environmental chemistry at the University of Ibadan (UI), former director at the Basel Convention Regional Co-ordinating Centre for Africa in UI, and a board member of Sustainable Electronic Recycling International (SERI), United States.

$110 \quad$ OKORHI et al (n 64) 1388.

111 YOUNG (n 107).

112 Ibid. 
'a volume that is going to encourage a big recycler to invest in building the necessary infrastructure. 113

Understandably, an argument supporting the transboundary movement of e-waste into Nigeria is contrary to the recommendations proffered under the PiP report, ${ }^{114}$ and to a certain extent, the Basel Convention E-waste African Programme, ${ }^{115}$ on the stricter enforcement of the legislation prohibiting the transboundary movement of e-waste into Nigeria. However, considering the militating factors discussed in the preceding section, a stricter enforcement of this legislation is arguably utopian and unattainable in the near or foreseeable future, particularly against the imports of e-waste, especially through used vehicles. Indeed, even as acknowledged by the PiP report, the resort to the importation through used vehicles in Nigeria (currently a major e-waste importation route, as noted above), may have been motivated by the need to avoid compliance with the requirements of the EEE Sector Regulations. ${ }^{116}$ Similarly, the recommendation by the PiP report on the need to strengthen the inspection approach and methodology at Nigerian ports, particularly the roll-on-roll-off (RoRo) imported vehicles, ${ }^{117}$ is largely unattainable as it fails to take into cognizance the unwieldy nature of port operations as well as the understaffing and other resource constraints of regulatory agencies in Nigeria.

Regarding the latter, the sheer volume of imported used vehicles and their contents, including e-waste, would overwhelm the regulatory capacity of both NESREA and NCS. Indeed, monitoring and detecting such illegal e-waste shipments is 'the ultimate hunt for the needle in a haystack'.118 This perhaps explains why NESREA is principally focused on regulating imports through containers, which in any event remains poorly regulated and depends mostly on the registration system and whistleblowing by international organizations like Interpol. Even if NESREA were to be adequately staffed and funded, it is doubtful if they would be allowed to have a permanent presence in the Nigerian ports that would optimize their operational effectiveness against the transboundary movement of e-waste into Nigeria. This is due to the unwieldy nature of port operations in Nigeria which would cause their presence to encumber the ease of doing business at these ports. The general belief

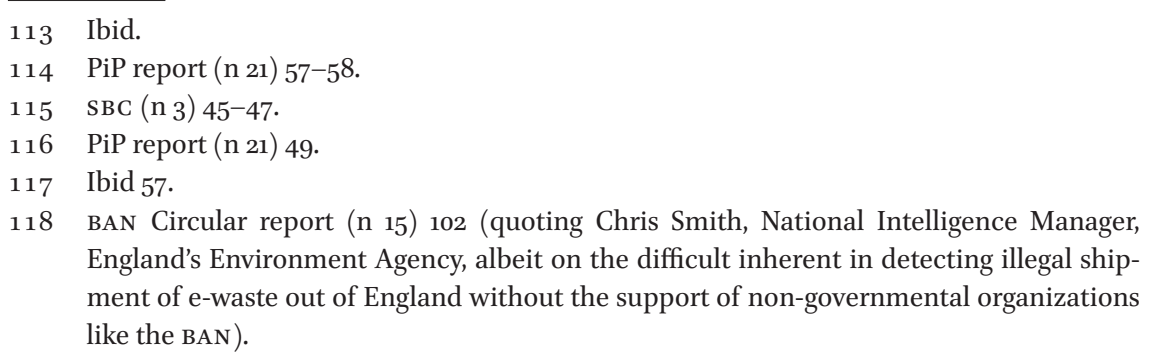


is that Nigerian ports are 'the most expensive in West Africa largely because of the activities of the several government agencies [including NESREA] that are a regular feature of the port system.. ${ }^{119}$ To address this, the federal government recently enforced its 2011 presidential directive on agencies permitted to operate in the port locations, and which expressly excluded agencies such as NESREA from operating within Nigerian seaports. ${ }^{120}$ The implication is that NESREA can only be invited into the ports by the NCS with respect to the clearing of any controlled item. ${ }^{121}$

\subsection{Learning from Ghana's Experience in Regulating the Imports of E-waste}

Ghana is an example of an African country that seeks to maximize the socioeconomic benefits offered by transboundary movement of e-waste while minimizing the negative environmental and human health impacts. As noted earlier, it ranks behind Nigeria as the second largest importer of e-waste in Africa. In fact, for a brief period in 2010, when stronger enforcement by the Nigerian government made it less attractive to import e-waste through containers, Ghana was arguably the highest importer of e-waste. ${ }^{122}$ Such imports are driven by the same factors that drive the demand for used EEE and consequently the rapid increase in the importation of the equipment into Nigeria. ${ }^{123}$ Again, just like in Nigeria, the high imports of used EEE including nonfunctional equipment, has led to the domestic generation of relatively high volumes of e-waste in Ghana, with obvious adverse environmental and human

119 'Government Agencies in Nigerian Ports' Shipping Position, 9 October $2011<$ http://ship ping position.com.ng/content/government-agencies-nigerian-ports>. See also Samson Echenim, 'Return of FG Agencies Threatens 48-Hour Cargo Clearance Target' NBF News, 9 July $2012<$ http://<www.nigerianbestforum.com/blog/return-of-fg-agencies-threatens -48-hour-cargo-clearance-target>/; 'NAGAFF faults NESREA's presence @ ports' Ships \& Ports, 13 February $2013<$ http://shipsandports.com.ng/nagaff-faults-nesreas-presence -ports/>; 'NESREA's presence at ports counter-productive, NBCC' Vanguard, 28 April 2010 $<$ http://www.nigeria70.com/nigerian_news_paper/nesrea'spresence_at_ports_counter _productive_nbcc/211234> and 'SON, NESREA Others Sneaking Back into Ports, ANLCA

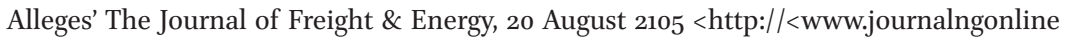
.com/2015/08/20/son-nesrea-others-sneaking-back-into-portsanlca-alleges/>.

120 Nigerian Ports Authority (NPA), 'List of Government Agencies Domiciled at Port Locations' Press Release, 12 February $2018<$ http://nigerianports.gov.ng/2018/o2/13 /list-of-government-agencies-domiciled-at-port-locations/>.

121 Ibid.

122 SBC (n 3$) 21$.

123 Ibid 22 and $30-32$. See also BURRELL (n 88) and M OTENG-ABABIO, 'Electronic Waste Management in Ghana-Issues and Practices' in S CURKOVIC (ed), Sustainable Development-Authoritative and Leading Edge Content for Environmental Management (2012) 149-167 155-56. 
health consequences. ${ }^{124}$ As pointed by the Basel Convention E-waste African Programme, a sampling operation carried out by Greenpeace at the main informal recycling sites in Ghana, including the infamous Agbogbloshie dump site, ${ }^{125}$ 'revealed that copper, lead, tin and zinc concentrations in soil and ash samples are over one hundred times higher than typical background levels.' ${ }^{126}$ Thus, it was not surprising that the initial reaction by the Environmental Protection Agency (EPA) was to agitate for the adoption of a law that would make the import of e-waste illegal in Ghana. ${ }^{127}$

However, in legislating on the transboundary movement of e-waste, Ghana opted for the regulation and sustainable management of e-waste imports rather than prohibiting such imports, as is the practice in Nigeria. ${ }^{128}$ This policy position is evident in the overall objective of the Hazardous and Electronic Waste Control and Management Act, ${ }^{129}$ which is the 'control, management and disposal of hazardous waste and electronic waste and for related purposes.' ${ }^{130}$ E-waste that falls under the description of hazardous waste under the Act ${ }^{131}$ is defined as 'discarded electronic equipment inclusive of all components, subassemblies, and consumables which are part of the product as the time of discarding'.132 This definition is similar to that under the Nigerian EEE Sector Regulations, as it brings all end-of-life and non-functional EEE within the purview of the Act. ${ }^{133}$ Specifically, as it concerns the transboundary movement of e-waste, the import and export of all used EEE including e-waste is prohibited unless the person involved complies with the conditions provided

124 Ibid 21-26. See also K DAUM, J STOLER and RJ GRANT, 'Toward a More Sustainable Trajectory for E-Waste Policy: A Review of a Decade of E-Waste Research in Accra, Ghana' (2017) 14 International Journal of Environmental Research and Public Health135-152 13840; and J AKBAR, 'Africa's "electronic graveyards" where the west dumps PCs, laptops and more' Daily Mail, 23 April 2015 <www.dailymail.co.uk/news/article-3049457/Wher e-computer-goes-die-Shocking-pictures-toxic-electronic-graveyards-Africa-West-dumps -old-PCs-laptops-microwaves-fridges-phones.html>.

125 Once described as the world's largest e-waste dump: see Burrell (n 88).

126 Sвс (n 3) 25.

127 This is evident in the statement credited to EPA deputy director Lambert Faabeluon. See 'Ghana's poor eke out a living from toxic e-waste', Sunday Times, 30 October $2013<w w w$ .timeslive.co.za/news/sci-tech/2013-10-30-ghanas-poor-eke-out-living-in-toxic-e-waste/>.

128 M LIDDANE, 'Ghana is the Shining Star for e-Waste Law in Africa' Compliance and Risks, 25 July 2016 <https://<www.complianceandrisks.com/ghana-is-the-shining -star-for-e-waste-law-in-africa/>.

129 Ghana's Hazardous Wastes Act (n 18).

130 Ibid.

131 Ibid s 1(1).

132 Ibid 37.

133 Ibid (for further understanding of what constitutes e-waste under the Act can be gleaned from its definition of used equipment). 
under the Act. ${ }^{134}$ These conditions include registering and obtaining an import or export permit from the EPA, and the payment of the advanced eco-levy as stipulated in the fifth schedule to the Act. ${ }^{135}$ It is noted that in instances of the importation of e-waste for recycling purposes, the EPA is empowered to grant a permit without the payment of the eco-levy. ${ }^{136}$ This is a curious provision considering the importance of the eco-levy as a source of money for the EEE Waste Management Fund that is expected to provide finance for the sustainable management of e-waste and reduction of its adverse impact on human health and the environment. ${ }^{137}$ Perhaps, its utility lies in promoting Ghana as a destination of choice for the recycling of e-waste.

Unarguably, such imports would increase the volume of domestic generation of e-waste in Ghana. Nevertheless, it is envisaged that the Act would ultimately encourage the establishment of recycling plants by local and foreign investors that would not only create job opportunities but also help in tackling the environmental impact of improper treatment and management of e-waste in the country. ${ }^{138}$ This mindset is aptly encapsulated in the statement credited to Simon Edem Asimah, Chairman of the Committee on Environment, Science and Technology of the Parliament of Ghana as follows:

And I want to put on record that this Act has certain fundamental issues that are going to come up and as a result, we tried to find out from the consultant to the $\{\mathrm{M}]$ inistry and we came out with this Act and it came out clearly that it is going to create jobs. In fact, they talked about over six hundred thousand jobs $(600,000)$ to be created, especially for those who are going to be involved in the collection jobs because when the recycling plants are established, jobs will be created over there. For example, when you go to Agblogbloshie, I think Agblogbloshie is one of the biggest electrical and electronic waste treatment centres in the country and you see a number of people who are engaged over there but do not enhance the

134 Ibid s 20(1). Any contravention makes the guilty party to be liable to the payment of 'an administrative penalty equivalent to twice the amount of the levy payable in respect of the electrical and electronic equipment'. See s $20(4)$.

135 Ibid. The eco-levy forms one of the sources of money for the Electrical and Electronic (EE) Waste Management Fund established under the Act. See ss 23-30, concerning the establishment, object, sources of money and management of the Fund.

136 Ibid s 2o(3).

137 Ibid s 24 .

138 Ibid ss 24 and 28 (providing for the use of the e-waste fund proposed under the Act for research into e-waste treatment and recycling, and the construction of recycling plants and other related activities). See also United Nations Environment Programme (UNEP), 'Turning e-waste into gold: the untapped potential of African landfills' 24 September 2018. 
environmental aspect of their job especially when it is also harmful to their health. So this time it will be organized in a very nice way. ${ }^{139}$

The adoption of the Act by Ghana's parliament constitutes a significant lesson for policy makers in Nigeria on how to use the instrument of the law in promoting and harnessing the socio-economic opportunities and environmental potentials offered by the importation of e-waste. It is worth noting that the ban placed by Nigeria on the imports of e-waste has not translated to the better environmental management of the e-waste generated domestically within the country due to the lack of formal recycling facilities. It should also be noted that in adopting this policy position with regard to the importation of e-waste, Ghana is following the precedent laid down by some African countries such as South Africa and Kenya, whose policies have encouraged the establishment of large-scale e-waste recycling facilities. ${ }^{140}$ In this regard, the enabling regulatory framework has allowed South Africa to boast a more sophisticated recycling and disposal infrastructure, that caters not only for domestic wastes but also for wastes from Southern Africa Development Community (SADC) countries that '... do not have adequate disposal facilities in their own country to dispose of the waste in an environmentally sound manner. ${ }^{\prime 11}$ A similar scenario pertains in Kenya with the adoption of the 2013 Environmental Management and Co-Ordination (E-Waste Management) Regulations, ${ }^{142}$ although the import of e-waste for recycling purposes is restricted only to African countries. ${ }^{143}$

Understandably, the implementation of the Hazardous Wastes Act in Ghana is still at the embryonic stage, with only the commencement of the eco-levy on 1 October 2018. ${ }^{144}$ Thus, it is presently difficult to predict with certainty that the

139 Quoted in 'Hazardous and Electronic Waste Control and Management Act, 2016: Recycling Plants to create almost 600 thousand jobs for Ghanaians-MP' Ghana Justice, 16 June 2016 <http://ghanajustice.com/hazardous-and-electronic-waste-control -and-management-act-2016-recycling-plants-to-create-almost-6oo-thousand-jobsfor -ghanaians-mp/>.

140 For instance, Dell in collaboration with the Kenyan government and representatives from NGOs, and the IT and e-recycling industries, developed East Africa Compliant Recycling - the region's first large-scale e-waste recycling facility. Green I.T. (n 108).

141 Secretariat of Basel Convention ( $\mathrm{SBC}$ ), 'Basel Convention Country Fact Sheet: South Africa (2009)' <www.basel.int/Countries/Countryfactsheets/tabid/1293/ctl/Down load $/ \mathrm{mid} / 8404 /$ Default.aspx?id=63\&ObjID=117 $>$ (hereinafter SA Country Fact Sheet).

142 Kenyan E-waste Regulations (n 18).

143 Ibid reg 22 (providing that no person shall import any e-waste from outside Africa into Kenya).

144 There are also reports that a $\$ 30$ million e-waste recycling facility will be built at Agbogbloshie in Accra. See Paul PLOUMIS, 'Construction of \$30M Ghana E-Waste Recycling Facility to Begin This Year' ScrapMonster, 13 August $2018<$ https://<www.scrap monster.com/news/construction-of-3om-ghana-ewaste-recycling-facility-to-begin-this 
Hazardous Waste Act has enabled the country to tackle the environmental and health impacts of the e-waste transnational trade while maximizing the socio-economic benefits. Despite this, the prospects of achieving the objectives of the Act and creating a framework for the sustainable management of e-waste appear to be promising. Presently, several donor agencies such as the German Federal Ministry for Economic Cooperation and Development (GIZ), ${ }^{145}$ the European Union, ${ }^{146}$ and the Swiss State Secretariat of Economic Affairs $(\operatorname{sECO}),{ }^{147}$ are funding and collaborating with the Ministry of Environment, Science, Technology and Innovation (MESTI), and the EPA on projects that will promote the environmentally sound disposal and recycling of e-waste in Ghana. ${ }^{148}$ This should be a boost to Nigerian policymakers in adopting Ghana's approach by reversing the ban on imports of e-waste.

The only difference is that, unlike Ghana's approach, the administrative fees already introduced for the import of new and used EEE into Nigeria under the EEE Sector Regulations should be extended to cover e-waste. This is borne out of the fear that importers might resort to false declaration of their goods in order to avoid paying the cost. This is not misplaced since, as earlier recurred, importers of used EEE are already falsely declaring their goods as merely used items in order to avoid the payment of the fees. Perhaps, the most important limitation to adopting Ghana's approach is that Nigeria may lack the necessary political will to implement proposed amendments to the existing e-waste

-year/1/68620> and 'Gov't to build E-waste recycling facility in Agbogbloshie' Myjoyonline, 29 August $2018<$ https://<www.myjoyonline.com/news/2018/August-29th/govt-to-build -e-waste-recycling-facility-in-agbogbloshie.php >.

145 German Federal Ministry for Economic Cooperation and Development (GIZ), 'Environmentally Sound Disposal and Recycling of E-waste in Ghana (E-Waste project)' $<$ https://<www.giz.de/en/worldwide/63039.html>; and Dennis DELA SETSOAFIA, 'Ghana's Biggest E-Waste Yard Receives Face-Lift' MESTI News, 28 March 2019, $<$ http://<mesti.gov.gh/ghanas-biggest-e-waste-yard-receives-face-lift/>.

146 Morton HEMKHAUS, 'From Grave to Cradle: E-waste Management in Ghana (E-MAGIN Ghana)' <https://www.adelphi.de/en/project/grave-cradle-e-waste-management-ghana -e-magin-ghana $>$.

147 Sustainable Recycling Industries (SRI), 'Ghana's way towards sustainable e-waste recycling-First country in Africa to officially launch guidelines for environmentally sound e-waste management' 5 March 2018 <https://<www.sustainable-recycling.org /ghanas-way-towards-sustainable-e-waste-recycling-first-country-in-africa-to-officially -launch-guidelines-for-environmentally-sound-e-waste-management/>.

148 For instance, the collaboration with SEco led to the drafting and adoption of the Technical Guidelines on Environmentally Sound E-Waste Management. See Environmental Protection Agency (EPA) and Sustainable Recycling Industries (SRI), the Technical Guidelines on Environmentally Sound E-Waste Management for Collectors, Collection Centers, Transporters, Treatment Facilities and Final Disposal in Ghana (February 2018) <https://<www.sustainable-recycling.org/wp-content/uploads/2018/03 /eWaste-Guidelines-Ghana_2018_EPA-SRI.pdf >. 
legislation/regulations, if ever enacted or adopted, thereby exacerbating the e-waste situation in the country.

The failure of the existing ban on transboundary movement of e-waste into Nigeria makes it necessary for the policymakers to come up with new and innovative means to address the environmental and human health impacts associated with the imports. Admittedly, the Nigerian position mirrors the popular regulatory responses that have principally focused on banning transboundary shipments of e-waste. ${ }^{149}$ However, for inter-related factors that are mostly socio-economic in character, this policy response has been weakly promoted, and hence largely ineffective in eliminating the transboundary movement of e-waste into Nigeria. This article therefore advocates for a policy shift from prohibiting the imports of e-waste to the regulation and sustainable management of such imports, as is evident from the experience in Ghana. In this respect, NESREA is urged to amend the EEE Sector Regulations by removing the provisions that criminalise the importation of e-waste into Nigeria. This would not only enable Nigeria to harness the socio-economic benefits arising from such imports, but would also enable the establishment of formal recycling facilities that would ultimately lead to better environmental management of e-waste within the country. Such a policy shift would not require many changes to the existing regulatory framework on e-waste, as the EEE Sector Regulations already provides for the registration of all importers of EEE; establishment and sustainable management of recycling facilities in Nigeria, as well as requiring the payment of an administrative cost on all imports of new and used EEE. The latter should be extended to cover import of e-waste as it would help in the environmentally sound management of the waste in Nigeria. The proposed extension of the administrative cost to imports of e-waste differs from the position under the Hazardous Waste Act in Ghana. However, it would avoid a scenario whereby importers of used EEE would start to falsely declare their goods as e-waste in order to avoid the payment of the fees.

149 See generally, Danish Environmental Protection Agency, Import restrictions on used electric and electronic equipment, Guidance document no. 15 (2015) <https:/ $<$ www2.mst.dk /Udgiv/publications/2016/01/978-87-93435-07-0.pdf>. 